\title{
FAKTOR-FAKTOR YANG BEHUBUNGAN DENGAN HIPOTERMI PADA PASIEN PASCA GENERAL ANESTESI
}

\author{
Fitra Pringgayuda ${ }^{1}$, Purbianto, ${ }^{2}$ Ari Eko Putra ${ }^{3}$ \\ ${ }^{1}$ Universitas Muhammadiyah Pringsewu, Lampung, Indonesia \\ ${ }^{2}$ Poltekes Kemenkes Tanjungkarang, Lampung, Indonesia \\ ${ }^{3}$ RS Graha Husada Bandar Lampung, Lampung, Indonesia \\ *E-mail: fpringgayuda@yahoo.com
}

\begin{abstract}
Abstrak
Salah satu komplikasi yang akan muncul setelah tindakan anestesi general adalah hipotermi. Hipotermia perioperatif sering terjadi dan dapat menyebabkan beberapa komplikasi, yang berdampak buruk pada pasien. Dampak negatif hipotermi terhadap pasien, antara lain risiko perdarahan meningkat, iskemia miokardium, pemulihan pasca anestesi yang lebih lama, gangguan penyembuhan luka, serta meningkatnya risiko infeksi. Penelitian ini bertujuan untuk mengetahui factor-faktor yang berhubungan dengan hipotermi pada pasien pasca general anestesi di Instalasi Bedah Sentral Rumah Sakit Graha Husada Bandar Lampung. Metode penelitian: Penelitian kuantitatif menggunakan desain observasi analitik dengan pendekatan cross sectional. Sampel dipilih menggunakan Teknik consecutive sampling sebanyak 30 responden. Pengambilan data dilakukan pada tanggal 3 Mei-29 Juni 2019 dengan menggunakan lembar observasi. Hasil penelitian: Analisis uji uji Chi-Square menunjukkan bahwa faktor yang berhubungan dengan Hipotermi pasca general anestesi adalah usia $(\mathrm{p}=0,003)$, dengan IMT $(p=0,021)$ dan lama operasi $(p=0,011)$ dan tidak ada hubungan antara kejadian hipotermi dengan jenis kelamin $(\mathrm{p}=0,123)$ di Instalasi Bedah Sentral Rumah Sakit Graha Husada Bandar Lampung. Kesimpulan: ada hubungan antara usia, dan lama operasi.
\end{abstract}

Kata Kunci: faktor, general anestesi, hipotermi

\begin{abstract}
One of the complications that will arise after the general anesthesia is hypotermi. Perioperative hypothermia often occurs and can cause some complications, which adversely affect the patient. Negative impacts of hypothermi against patients, such as increased risk of bleeding, myocardial ischemia, prolonged post-anesthesia recovery, wound healing disorders, as well as increased risk of infection. This research aims to determine the factors related to hypotermi in post-general anesthesia patients at the central surgical installation of Graha Husada Hospital, Bandar Lampung. This is a quantitative research using analytic observation design with cross sectional approach. The sample was selected using the consecutive sampling technique by 30 respondents. Data retrieval is conducted on 3 May-29 June 2019 using observation sheet. The results of chi-Square test showed that the factors related to Hypotermi post-general anesthesia are age $(P=0,003)$, with BMI $(P=0,021)$ and duration of operation $(p=0,011)$ and no relationship between the occurrence of Hypothermi with Gender $(P=$ $0,123)$ in the central surgical installation of Graha Husada Hospital in Bandar Lampung. Conclusion: There is a relationship between age, and duration of operation.
\end{abstract}

Keywords: factor, general anesthesia, hipothermi 


\section{PENDAHULUAN}

General anastesi salah satu yang dapat memicu perubahan fisiologis yang mungkin terjadi, diantaranya komplikasi perdarahan, irama jantung tidak teratur, gangguan pernafasan, sirkulasi, pengontrolan suhu (hipotermi), serta fungsi-fungsi vital lainnya seperti fungsi neurologis, integritas kulit dan kondisi luka, fungsi genitourinaria,gastrointestinal, keseimbangan cairan dan elektrolit serta rasa nyaman (Potter, 2005; Sjamsuhidajat \& Wim De Jong, 2017; Guyton, 2008; Smeltzer, 2002). Menurut beberapa peneliti salah satu komplikasi yang akan muncul setelah tindakan pembedahan dengan general anestesi adalah hilangnya proses adaptasi serta mengganggu fisiologis termoregulasi dan memiliki angka kematian hampir 50\% (Harahap, 2014; Setiyanti, 2016; Hanifah, 2017). Faktor Indeks Massa Tubuh (IMT) berhubungan dengan kejadian hipotermi sebanyak 92,3\%, perempuan $51,2 \%$ kejadian hipotermi saat pembedahan general anastesi dibandingkan laki-laki, dan $65,5 \%$ pasien pasca general anastesi sebagian besar mengalami hipotermi (Engber, 2014, Harahap, 2014; Hanifa, 2017).

Berdasarkan Hasil studi pendahuluan yang dilakukan dengan wawancara pada pegawai khsusunya bagian anestesi Rumah sakit Graha Husadapada, peneliti mendapatkan hasil, yaitu pasien dengan operasi general anestesi rata-rata 150 orang setiap bulannya. Didapatkan juga data jumlah operasi dari januari-maret rata-rata jumlah operasi sebanyak 300, jumlah ini lebih banyak dibandingkan jumlah operasi di RS tipe $\mathrm{C}$ di Bandar lampung. Data hipotermi juga didapatkan dari bulan januari s/d maret adalah 50 pasien. Oleh karena itu, peneliti memilih responden yang menjalani operasi dengan general anestesi di Instalasi Bedah Sentral (IBS) Rumah sakit Graha Husada sebagai sampel yang digunakan untuk penelitian, dari data tersebut maka peneliti tertarik untuk melakukan penelitian tentang faktorfaktor yang berhubungan dengan hipotermi pada pasien pasca general anestesi di IBS Rumah Sakit Graha Husada Bandar Lampung.

\section{METODOLOGI}

Penelitian ini merupakan penelitian kuantitatif observasional analitik dengan cross sectional di Instalasi Bedah Sentral RS Graha Husada Bandar lampung. Pengambilan data dilakukan pada 3 Mei sampai dengan 29 Juni 2019. Populasi dalam penelitian ini adalah pasien yang menjalani operasi dengan general anestesi di RS Graha Husada. Jumlah operasi 3 bulan sebelum penelitian didapatkan rata- 
rata 300 pasien. Penelitian ini dilakukan di IBS RS Graha Husada Bandar lampung pada bulan april-mei tahun 2019. Sampel pada penelitian ini diambil menggunakan teknik consecutive sampling berjumlah 30 pasien dengan kriteria inklusi yaitu, pasien dengan usia $>17$ tahun, pasien elektif/cito dengan general anestesi, pasien dengan operasi pada regio dada dan abdomen serta regio femur.

Penelitian ini menggunakan variabel independent dan dependen yaitu factorfaktor yang berhubungan dengan hipotermi pada pasien dengan general anastesi dilihat dari karakteristik usia, IMT, jenis kelamin, dan lama operasi. Sedangkan variabel dependen yaitu kejadian hipotermi pasca general anestesi di IBS Rumah Sakit Graha Husada Bandar Lampung. Instrumen yang digunakan adalah lembar observasi. Analisa data penelitian ini menggunakan univariat, bivariat menggunakan uji chisquare.

\section{HASIL}

\section{Analisa Univariat}

\section{a. Jenis Kelamin}

Tabel 1. Distribusi Responden Menurut Jenis Kelamin Pada Pasien Post General Anestesi

\begin{tabular}{lcc}
\hline Jenis Kelamin & $\mathrm{F}$ & $\%$ \\
\hline Perempuan & 17 & 56,7 \\
Laki-laki & 13 & 43,3 \\
Total & 30 & 100 \\
\hline
\end{tabular}

Berdasarkan tabel 1 dapat diketahui bahwa sebagian besar responden berjenis kelamin perempuan yaitu sebanyak $17(56,7 \%)$.

\section{b. Usia}

Tabel 2 Distribusi Responden Menurut Usia Pada Pasien post General Anestesi

\begin{tabular}{lcc}
\hline Usia & $\mathrm{f}$ & $\%$ \\
\hline Lansia (> 46 tahun) & 22 & 73,3 \\
Dewasa (17-45) & 8 & 26,7 \\
Total & 30 & 100 \\
\hline
\end{tabular}

Berdasarkan tabel 2 dapat diketahui bahwa responden sebagian besar adalah berusia lansia yaitu ada $22(73,3 \%)$.

\section{c. Indeks Masa Tubuh (IMT)}

Tabel 3 Distribusi Responden Menurut IMT Pada Pasien post General Anestesi

\begin{tabular}{lcc}
\hline IMT & F & $\%$ \\
\hline$<25,0$ & 27 & 90,0 \\
$\geq 25,0$ & 3 & 10,0 \\
Total & 30 & 100 \\
\hline
\end{tabular}

Berdasarkan tabel 3 dapat diketahui bahwa responden sebagian besar adalah dengan IMT $<25,0$ sebanyak 27 (90\%).

\section{d. Lama operasi}

Tabel 4 Distribusi Responden Menurut Lama operasi Pada Pasien post General Anastesi

\begin{tabular}{llc}
\hline Lama operasi & $\mathrm{F}$ & $\%$ \\
\hline$>2$ jam & 11 & 36,7 \\
$\leq 2$ jam & 19 & 63,3 \\
Total & 30 & 100 \\
\hline
\end{tabular}

Berdasarkan tabel 4 dapat diketahui bahwa responden sebagian besar mengalami operasi yaitu selama 1-2 jam sebanyak $10(33,3 \%)$. 


\section{e. Hipotermi}

Tabel 5 Distribusi Responden Menurut Hipotermi Pada Pasien post General Anestesi

\begin{tabular}{lccc}
\hline \multicolumn{2}{l}{ Suhu } & F & $\%$ \\
\hline$<36,0$ (Hipotermi) & 21 & 70 \\
$>\quad 36,0 \quad$ (Tidak & 9 & 30 \\
$\begin{array}{l}\text { Hipotermi ) } \\
\text { Total }\end{array}$ & & 30 & 100 \\
\hline
\end{tabular}

Berdasarkan tabel 5 dapat diketahui bahwa sebagian besar responden adalah mengalami hipotermi sebanyak 21 (70\%).

\section{Analisis Bivariat}

\section{a. Hubungan Faktor Jenis Kelamin dengan Hipotermi Pasca General Anestesi}

Tabel 6 Hubungan Jenis Kelamin dengan Hipotermi Pada Pasien Pasca General Anestesi di IBS RS Graha Husada Bandar Lampung 2019

\begin{tabular}{|c|c|c|c|c|c|c|c|c|}
\hline \multirow{3}{*}{$\begin{array}{c}\text { Jenis } \\
\text { Kelamin }\end{array}$} & \multicolumn{4}{|c|}{ Hipotermi } & \multirow{2}{*}{\multicolumn{2}{|c|}{ Total }} & \multirow{3}{*}{$\begin{array}{c}\text { OR } \\
(95 / \\
\% \\
\text { CI })\end{array}$} & \multirow{3}{*}{$\begin{array}{l}p- \\
\text { val } \\
\text { ue }\end{array}$} \\
\hline & & $\mathrm{Ya}$ & & idak & & & & \\
\hline & $\mathrm{F}$ & $\%$ & f & $\%$ & f & $\%$ & & \\
\hline $\begin{array}{l}\text { Perempu } \\
\text { an }\end{array}$ & 14 & $\begin{array}{c}82, \\
4\end{array}$ & 3 & $\begin{array}{c}17 \\
6\end{array}$ & 17 & $\begin{array}{c}10 \\
0\end{array}$ & 4,0 & \\
\hline $\begin{array}{l}\text { Laki- } \\
\text { Laki }\end{array}$ & 7 & $\begin{array}{c}53 \\
8\end{array}$ & 6 & $\begin{array}{c}46, \\
2\end{array}$ & 13 & $\begin{array}{c}10 \\
0\end{array}$ & 00 & $\begin{array}{l}0,1 \\
23\end{array}$ \\
\hline Total & 21 & 70 & 9 & 30 & 30 & $\begin{array}{c}10 \\
0\end{array}$ & & \\
\hline
\end{tabular}

Berdasarkan tabel 6, responden dengan jenis kelamin perempuan yang mengalami hipotermi ada 14 (82,4\%). Sedangkan responden dengan jenis kelamin laki-laki yang mengalami hipotermi sebanyak 7 $(53,8 \%)$. Hasil uji statistik diperoleh nilai $p$-value $=0,123>\alpha(0.05)$ artinya $\mathrm{H}_{0}$ diterima sehingga dapat disimpulkan bahwa tidak terdapat hubungan antara jenis kelamin dengan kejadian hipotermi pada pasien pasca general anestesi. Dari hasil analisis diperoleh pula nilai $\mathrm{OR}=4,000$. Hasil penelitian ini menunjukkan bahwa tidak terdapat hubungan antara jenis kelamin kejadian hipotermi.

Hal ini tidak sesuai dengan penelitian yang dilakukan Harahap (2014), angka hipotermi lebih banyak terjadi pada perempuan daripada laki-laki, yaitu sebanyak 51,2\% dengan hasil uji statistik $p$-value $<0,05$ yaitu $p=0,013$ yang berarti terdapat perbedaan yang bermakna antara laki-laki dan perempuan dengan kejadian hipotermi. Ini juga didukung oleh penelitian Setiyanti (2015) bahwa sebanyak $13(81,2 \%)$ pasien dari 16 pasien mengalami hipotermi pada kelompok kontrol dan sebanyak 10 orang $(62,5 \%)$ mengalami hipotermi pada kelompok perlakuan.

Beberapa penyebab hipotermi di kamar operasi adalah: suhu kamar operasi yang dingin, penggunaan desinfektan, cairan infus dan transfusi darah, cairan pencuci rongga pada daerah operasi, kondisi pasien (usia), dan penggunaan obat anestesi. Dari penjelasan teori diatas jelas tidak ditemukan pernyataan bahwa jenis kelamin dominan dalam mempengaruhi hipotermi 
pasca operasi dengan anestesi general (Mangku \& Senapathi, 2010).

\section{b. Hubungan Faktor Usia dengan Hipotermi Pasca General Anestesi}

Tabel 7. Hubungan Usia dengan Hipotermi Pada Pasien Pasca General Anestesi di IBS RS Graha Husada Bandar Lampung 2019

\begin{tabular}{|c|c|c|c|c|c|c|c|c|}
\hline \multirow{3}{*}{ Usia } & \multicolumn{4}{|c|}{ Hipotermi } & \multicolumn{2}{|c|}{ Total } & \multirow{3}{*}{$\begin{array}{c}\text { OR } \\
(95 / \\
\% \\
\text { CI })\end{array}$} & \multirow{3}{*}{$\begin{array}{l}p- \\
\text { val } \\
\text { ue }\end{array}$} \\
\hline & \multicolumn{2}{|c|}{$\mathrm{Ya}$} & \multicolumn{2}{|c|}{ Tidak } & & & & \\
\hline & $\mathrm{F}$ & $\%$ & $\mathrm{~F}$ & $\%$ & $\mathrm{~F}$ & $\%$ & & \\
\hline $\begin{array}{l}>46 \\
\text { (Lansi } \\
\text { a) }\end{array}$ & $\begin{array}{l}1 \\
9\end{array}$ & $\begin{array}{c}86, \\
4\end{array}$ & 3 & $\begin{array}{c}13 \\
6\end{array}$ & $\begin{array}{l}2 \\
2\end{array}$ & $\begin{array}{c}10 \\
0\end{array}$ & 19,0 & \\
\hline $\begin{array}{l}17-45 \\
\text { (dewa } \\
\text { sa) }\end{array}$ & 2 & $\begin{array}{c}25 \\
0\end{array}$ & 6 & $\begin{array}{c}75 \\
0\end{array}$ & 8 & $\begin{array}{c}10 \\
0\end{array}$ & 00 & 03 \\
\hline Total & $\begin{array}{l}2 \\
1\end{array}$ & 70 & 9 & 30 & $\begin{array}{l}3 \\
0\end{array}$ & $\begin{array}{c}10 \\
0\end{array}$ & & \\
\hline
\end{tabular}

Berdasarkan tabel 7, responden dengan usia > 46 tahun (lansia) yang mengalami hipotermi sebanyak $19 \quad(86,4 \%)$ ,sedangkan responden dengan usia 17-45 tahun (dewasa) yang mengalami hipotermi ada $2(25 \%)$. Hasil uji statistik didapatkan nilai $p$-value $=0,003<\alpha(0.05)$ artinya $\mathrm{H}_{0}$ ditolak sehingga dapat disimpulkan bahwa ada perbedaan proporsi kejadian hipotermi antara responden lansia dan dewasa (terdapat hubungan antara usia dengan kejadian hipotermi) pada pasien pasca general anestesi. Dari hasil analisis diperoleh pula nilai $\mathrm{OR}=19,000$. Penelitian ini sejalan dengan penelitian (Harahap, 2014) pasien lanjut usia termasuk kedalam golongan usia yang ekstrem, merupakan risiko tinggi untuk terjadi hipotermi pada periode perioperatif.

Angka kejadian hipotermi pada pasien lansia pasca anestesi di ruang pemulihan sebanyak 113 orang (87,6\%). General anestesi yang dilakukan pada pasien usia lansia juga dapat menyebabkan pergeseran pada ambang batas termoregulasi dengan derajat yang lebih besar dibandingkan dengan pasien yang berusia muda. Peneliti (Joshi, Shivkumaran, Bhargava, Kausara \& Sharma, 2006) juga menunjukkan kejadian hipotermia pada pasien lansia disebabkan perubahan fungsi kardiovaskular (kekakuan pada area dinding pembuluh darah arteri, peningkatan tahanan pembuluh darah perifer, dan juga penurunan curah jantung), kekakuan organ paru dan kelemahan otot-otot pernapasan mengakibatkan ventilasi, difusi, serta oksigenasi tidak efektif. Selain itu, pada lansia terjadi perubahan fungsi metabolik, seperti peningkatan sensitivitas pada reseptor insulin periferal, dan juga penurunan respon adrenokortikotropik terhadap faktor respon general anestesi umum yang dilakukan pada pasien usia geriatri dapat menyebabkan pergeseran pada ambang batas termoregulasi dengan 
derajat yang lebih besar dibandingkandengan pasien yang berusia muda. Hal itu disebabkan karena seseorang pada usia lansia telah terjadi kegagalan memelihara suhu tubuh dengan atau tanpa anestesi, kemungkinan hal ini terjadi karena penurunan vasokonstriksi termoregulasi yang terkait dengan usia (Kiekkas, 2007).

\section{Hubungan Faktor IMT dengan Hipotermi Pasca General Anestesi}

Tabel 8. Hubungan IMT dengan Hipotermi Pada Pasien Pasca General Anestesi di IBS RS Graha Husada Bandar Lampung 2019

\begin{tabular}{|c|c|c|c|c|c|c|c|}
\hline \multirow{3}{*}{ IMT } & \multicolumn{4}{|c|}{ Hipotermi } & \multirow{2}{*}{$\begin{array}{c}\text { Tota } \\
1\end{array}$} & \multirow{2}{*}{$\begin{array}{r}\text { OR } \\
(95 / \% \mathrm{CI})\end{array}$} & \multirow{3}{*}{$\begin{array}{c}P- \\
\text { Valu } \\
e\end{array}$} \\
\hline & \multicolumn{2}{|c|}{$\mathrm{Ya}$} & \multicolumn{2}{|c|}{$\begin{array}{c}\text { Tida } \\
\mathrm{k}\end{array}$} & & & \\
\hline & $\mathrm{f}$ & $\%$ & f & $\%$ & $\mathrm{~F}$ & $\%$ & \\
\hline \multirow[t]{2}{*}{$<25,0$} & 2 & 77 , & 6 & 22, & 2 & 100 & \\
\hline & 1 & 8 & & 2 & 7 & 222 & 0,021 \\
\hline$\geq 25,0$ & 0 & 0,0 & 3 & 100 & 3 & 100 & \\
\hline \multirow[t]{2}{*}{ Totall } & 2 & 70 & 9 & 30 & 3 & 100 & \\
\hline & 1 & & & & 0 & & \\
\hline
\end{tabular}

Berdasarkan tabel 8 diperoleh bahwa responden dengan IMT $<25,0$ yang mengalami hipotermi ada $21(77,8 \%)$, sedangkan responden dengan IMT $\geq 25,0$ yang mengalami hipotermi ada sebanyak 0 (100\%) . Hasil uji statistik dperoleh nilai p-value $=0,021<\alpha(0.05)$ artinya $\mathrm{H}_{0}$ ditolak sehingga dapat disimpulkan bahwa terdapat hubungan antara IMT dengan kejadian hipotermi pada pasien pasca general anestesi di IBS Rumah Sakit Graha Husada Bandar Lampung tahun 2019.

\section{Hubungan Faktor Lama Operasi dengan Hipotermi Pasca General Anestesi}

Tabel 9 Hubungan Lama Operasi dengan Hipotermi Pada Pasien Pasca General Anestesi di IBS RS Graha Husada Bandar Lampung 2019

\begin{tabular}{|c|c|c|c|c|c|c|c|c|}
\hline \multirow{3}{*}{$\begin{array}{l}\text { Lama } \\
\text { Operasi }\end{array}$} & \multicolumn{4}{|c|}{ Hipotermi } & \multicolumn{4}{|c|}{$O R$} \\
\hline & \multicolumn{2}{|c|}{$\mathrm{Ya}$} & \multicolumn{2}{|c|}{ Tidak } & \multicolumn{2}{|c|}{$\begin{array}{c}\text { Tota } \\
1\end{array}$} & $\begin{array}{c}(95 / \\
\% \\
\text { CI })\end{array}$ & $\begin{array}{c}P- \\
\text { Valu } \\
e\end{array}$ \\
\hline & $\mathrm{f}$ & $\%$ & $f$ & $\%$ & f & $\%$ & & \\
\hline \multirow[t]{2}{*}{$>2 \mathrm{Jam}$} & 1 & 10 & 0 & 0 & 1 & 10 & & \multirow{6}{*}{0,011} \\
\hline & 1 & 0 & & & 1 & 0 & 1 & \\
\hline \multirow[t]{2}{*}{$\leq 2 \mathrm{Jam}$} & 1 & 52 , & 9 & 47 , & 1 & 10 & 9 & \\
\hline & 0 & 6 & & 4 & 9 & 0 & 0 & \\
\hline \multirow[t]{2}{*}{ Total } & 2 & 70 & 9 & 30 & 3 & 10 & 0 & \\
\hline & 1 & & & & 0 & 0 & & \\
\hline
\end{tabular}

Berdasarkan tabel 9 diperoleh bahwa responden dengan lama operasi $>2$ jam yang mengalami hipotermi sebanyak 11 $(100 \%)$. Responden dengan lama operasi $\leq 2$ jam yang mengalami hipotermi sebanyak $10(52,6 \%)$. Hasil uji statistik dperoleh nilai $p$-value $=0,011<\alpha(0.05)$ artinya $\mathrm{H}_{0}$ ditolak sehingga dapat disimpulkan bahwa terdapat hubungan antara lama operasi dengan kejadian hipotermi pada pasien pasca general anestesi di IBS Rumah Sakit Graha Husada Bandar Lampung tahun 2019. 


\section{PEMBAHASAN}

Berdasarkan tabel 6, responden sebagian besar berjenis kelamin perempuan dan terbanyak juga yang mengalami hipotermi yaitu $17(100 \%)$. Hasil uji statistik didapatkan $p$-value $=0,123>\alpha(0.05)$ artinya $\mathrm{H}_{0}$ diterima sehingga dapat disimpulkan bahwa tidak terdapat hubungan antara jenis kelamin dengan kejadian hipotermi pada pasien pasca general anestesi di IBS Rumah Sakit Graha Husada Bandar Lampung tahun 2019.

Berdasarkan tabel 7 Responden sebagian besar berusia > 46 tahun (lansia) yang mengalami hipotermi sebanyak 19 $(86,4 \%)$ dan responden dengan usia 17-45 tahun (dewasa) yang tidak mengalami hipotermi sebanyak 2 (25\%). Hasil uji statistik didapatkan $p$-value $=0,003<\alpha$ (0.05) artinya $\mathrm{H}_{0}$ ditolak sehingga dapat disimpulkan bahwa terdapat hubungan antara usia dengan kejadian hipotermi pada pasien pasca general anestesi di IBS Rumah Sakit Graha Husada Bandar Lampung tahun 2019.

Dalam penelitian ini peneliti membagi menjadi dua kategori yaitu IMT $<25,0$ dan IMT $\geq 25,0$. Peneliti boleh menggabungkan katagori-katagori yang berdekatan dalam rangka memperbesar frekuensi harapan dari sel-sel tersebut (ini untuk tabel silang yang lebih dari $2 \times 2$ ) penelitian ini tentunya diharapkan tidak sampai membuat datanya kehilangan makna (Hastono,2016).

Berdasarkan tabel 8, responden dengan IMT < 25,0 yang mengalami hipotermi ada $21(77,8 \%)$. Responden IMT $\geq 25$ yang mengalami hipotermi sebanyak 0 (0\%). Hasil uji statistik didapatkan $p$-value $=0,021<\alpha(0.05)$ artinya $\mathrm{H}_{0}$ ditolak sehingga dapat disimpulkan bahwa terdapat hubungan antara IMT dengan kejadian hipotermi pada pasien pasca general anestesi di IBS Rumah Sakit Graha Husada Bandar Lampung tahun 2019. Penelitian ini juga didukung dengan penelitian Susilowati (2017) dan Suswitha (2018), hasil uji statistik menggunakan uji Chi Square yaitu $p$ value 0,005 $(p<0,05)$, kesimpulan penelitian bahwa terdapat hubungan IMT dengan kejadian mengigil pada pasien dengan spinal anestesi. Tingkat keeratan hubungan sedang.

Pada orang dengan IMT yang rendah akan lebih mudah kehilangan panas dan merupakan faktor risiko terjadinya hipotermi, hal ini dipengaruhi oleh persediaan sumber energi penghasil panas yaitu lemak yang tipis, simpanan lemak dalam tubuh sangat bermanfaat sebagai cadangan energi. Pada indeks massa tubuh yang tinggi memiliki system proteksi 
panas yang cukup dengan sumber energi penghasil panas yaitu lemak yang tebal sehingga IMT yang tinggi lebih baik dalam mempertahankan suhu tubuhnya dibanding dengan IMT yang rendah karena mempunyai cadangan energi yang lebih banyak (Valchanov et all, 2011).

Menurut Kartasapoetra (2008), dan Dirjen Gizi Masyarakat (2003), lemak merupakan sumber pembentuk energi di dalam tubuh, yang dalam hal ini bobot energi yang dihasilkan dari tiap gramnya lebih besar dari karbohidrat dan protein. Lemak juga berfungsi sebagai pembentuk susunan tubuh, pelindung kehilangan panas tubuh dan pengatur suhu tubuh. Orang yang memiliki IMT rendah yaitu memiliki lemak yang tipis dan mudah kehilangan panas karena simpanan lemak dalam tubuh sedikit sehingga hal tersebut dapat memicu kejadian shivering pada pasien dengan spinal anestesi.

Pada penelitian ini dilakukan uji crosstab antara IMT dengan hipotermi pada pasien pasca general anestesi menggunakan uji chi square didapatkan nilai signifikansi $\mathrm{p}$ value $0,021 \quad(\alpha=0,05)$. Dapat diketahui bahwa nilai signifikansi $<0,05 \quad(0,021<$ 0,05), maka Ho ditolak. Sehingga dapat dikatakan adanya hubungan antara IMT dengan hipotermi pada pasien pasca general anestesi di IBS RS Graha Husada
Bandar lampung tahun 2109. Menunjukkan bahwa ada hubungan antara IMT dengan hipotermi, yaitu semakin tinggi nilai IMT maka semakin menurun angka kejadian hipotermi. Hal itu bermakna, responden dengan IMT lebih (gemuk) memiliki risiko lebih rendah untuk mengalami hipotermi pasca general anestesi.

Berdasarkan tabel 9, diperoleh bahwa responden dengan lama operasi >2 jam yang mengalami hipotermi sebanyak 11 $(100 \%)$. Responden dengan lama operasi $\leq 2$ jam yang mengalami hipotermi sebanyak $10(52,6 \%)$. Hasil uji statistik didapatkan $p$-value $=0,011<\alpha(0.05)$ artinya $\mathrm{H}_{0}$ ditolak sehingga dapat disimpulkan bahwa terdapat hubungan antara lama operasi dengan kejadian hipotermi pada pasien pasca general anestesi di IBS Rumah Sakit Graha Husada Bandar Lampung tahun 2019.

Penelitian ini sesuai dengan penelitian yang dilakukan oleh Harahap (2014), berdasarkan hasil uji statistika menunjukkan bahwa terdapat hubungan yang bermakna antara lama tindakan operasi dengan kejadian hipotermi pada pasien pasca operasi sebanyak $(85,07 \%)$ dengan nilai $p$-Value $0,002<0,005$. 
Lama operasi dalam penelitian ini dihitung sejak dibuatnya sayatan pertama (time out) sampai pasien dipindahkan ke ruang pemulihan yang dinyatakan dalam jam. Depkes RI (2009), membagi operasi berdasarkan durasinya ke dalam 3 klasifikasi, yaitu cepat ( $<1$ jam), sedang (1-2 jam) dan lama (>2 jam). Hasil penelitian menunjukkan bahwa responden yang menjalani operasi dengan waktu 1-2 jam lebih banyak dan diantara mereka juga mengalami hipotermi terbanyak. Suhu ruangan operasi di IBS RS Graha Husada Bandar lampung dibuat menyesuaikan standar yaitu $19^{\circ} \mathrm{C}-24^{0} \mathrm{C}$ (Permenkes RI,2004).

Menurut Majid, Judha \& Istianah (2011); Syam (2013), hipotermi mungkin dialami pasien karena terpaparnya tubuh terlalu lama dengan suhu rendah kamar di ruang operasi $\left(<26,6^{0} \mathrm{C}\right)$. Selain itu, pasien yang menjalani operasi di IBS RS Graha Husada Bandar Lampung tidak menggunakan selimut penghangat selama operasi sampai dengan di ruang recovery room, sehingga tubuh pasien banyak terpapar dengan suhu ruangan kamar operasi yang dingin. Berdasarkan hasil uji crosstab yang telah dilakukan antara lama operasi dengan hipotermi pada pasien pasca general anestesi dengan menggunakan uji chi square didapatkan nilai signifikan $\mathrm{p}$-value $0,011(\alpha=0,05)$.
Sehingga dapat diketahui bahwa nilai signifikan $<0,05(0,011<0,05)$, maka Ho ditolak. Sehingga dapat disimpulkan ada hubungan antara lama operasi dengan hipotermi pada pasien pasca general anestesi di IBS RS Graha Husada Bandar lampung tahun 2019.

Pasien yang terpapar dengan suhu lingkungan yang dingin dapat mengalami kehilangan panas dari tubuhnya, dalam jumlah yang cukup banyak melalui beberapa proses atau mekanisme pengeluaran panas. Pada pasien operasi, pasien akan terpapar pada ruangan operasi dengan suhu yang dingin dalam waktu yang cukup lama sehingga menyebabkan terjadinya hipotermi pada pasien, Maulana (2018). Hal ini, berkaitan dengan lamanya tindakan operasi. Semakin lama dilakukan tindakan operasi maka akan ,semakin lama metabolisme akan menurun sehingga dalam waktu yang bersamaan pada tubuh akan berkurang produksi panas. Dengan demikian, itu akan mempercepat terjadinya proses hipotermi pada pasien (Suanda, 2014). Proses produksi serta pengeluaran panas tersebut diatur oleh tubuh guna mempertahankan suhu inti tubuh dalam rentang normotermia $\left(36^{0}-37,5^{\circ} \mathrm{C}\right)$ (Putzu, 2007). Dapat disimpulkan bahwa, pasien yang menjalani operasi dengan anestesi general yang lebih lama maka akan 
kehilangan panas secara bertahap dan lebih berisiko mengalami terjadinya hipotermi pasca operasi.

\section{KESIMPULAN}

Mayoritas responden berjenis kelamin perempuan, responden terbanyak berusia lansia, IMT responden sebagian besar normal, dan lama operasi terbanyak $>2$ jam. Hasil penelitian menunjukkan bahwa tidak ada hubungan antara faktor jenis kelamin, IMT dengan hipotermi pasca general anestesi, dan terdapat hubungan antara faktor usia, lama operasi dengan hipotermi pasca general anestesi, di IBS RS Graha Husada Bandar lampung.

\section{KEPUSTAKAAN}

Depkes RI. (2009). Sistem Kesehatan Nasional. Jakarta.

Direktorat Gizi Masyarakat. (2003). Petunjuk Teknis Pemantauan Status Gizi Orang Dewasa Dengan Indeks Massa Tubuh (IMT). Jakarta: Dirjen Bina Kesmas.

Engber, D. (2014). Fyi: Do Fat People Stay Warmer Than Thin People?. [Online] Available At: Http://Www.Popsci.Com/Article/ Science/Fyi-Do-Fat-People-Stay-
Warmer-Thin-People Accessed 17 Desember. 2018.

Guyton, A.C. \& Hall, J.E. (2008). Buku Ajar Fisiologi Kedokteran. Edisi 9, Jakarta: Egc.

Hanifa, A. (2017). Hubungan Hipotermi Dengan Waktu Pulih Sadar

Harahap, A. M. (2014). Angka Kejadian Hipotermia Dan Lama Perawatan Di Ibs Pada Pasien Geriatri Pascaoperasi Elektif Bulan Oktober 2011- Maret 2012 Di Rumah Sakit Dr.Hasan Sadikin Bandung. Jurnal Anestesi Perioperatif Volume 2(1) No: 3644. Fakultas Kedokteran Universitas Padjadjaran.

Joshi M, Shivkumaran S, Bhargava V,Kansara B, Sharma Rs. Perioperative Management Of The Geriatric Patient. J Indian Academy Of Geriatrics. 2006;2:28-33.

Kartasapoetra, G \& H. Marsetyo. (2008). Ilmu Gizi: Korelasi Gizi, Kesehatan Dan Produktivitas Kerja. Jakarta: Rineka Cipta.

Kiekkas, P, Et Al. (2007). Effects Of Hypothermia And Shivering On Standard PacuMonitoring Of 
Patients. Aana J. Vol. 73(1): 4753.

Majid, A., Judha, M., \& Istianah, U. (2011). Keperawatan perioperatif. Yogyakarta: Gosyen Publishing.

Maulana .(2018). Perbedaan Efektivitas

Terapi Cairan Hangat Dan Selimut Penghangat Terhadap Perubahan Suhu Tubuh Pada Pasien Pasca Operasi Di Ruang Pulih Instalasi Bedah Rsi Yatofa Pasca General Anestesi Di Ruang Pemulihan Rsud Wates. Prodi DIv Keperawatan Jurusan Keperawatan Politeknik Kesehatan Kementerian Kesehatan Tahun 2017.

Permenkes RI no. 1204 / MENKES / SK / X / 2004, tentang Persyaratan Kamar Operasi.

Potter, P.A., \& Perry, A.G. (2005). Buku Ajar Fundamental Keperawatan, Edisi 4. Jakarta: Egc.

Putzu, M. (2007). Clinical Complications, Monitoring And Management Of Perioperative Mild Hypothermia: Anesthesiological Features. Acta Biomed. Vol. 78: 163-9.

Setiyanti, W. (2016). Efektifitas Selimut Alumunium Foil Terhadap
Kejadian Hipotermi Pada Pasien Post Operasi Rsud Kota Salatiga. Skripsi S1 Keperawatan Stikes Kusuma Husada Surakarta (Dipublikasikan).

Sjamsuhidajat,De Jong.2017.Buku Ajar Ilmu Bedah : Masalah, Pertimbnagan Klinis Bedah Dan Metode Pembedahan.Jakarta :Egc.

Smeltzer, S.C \& Bare, B.G. (2002). Buku Ajar Medikal Bedah Edisi 8 Volume 2, Alih Bahasa Kuncara, H.Y, Dkk, Egc, Jakarta.

Suanda. (2014). Pemberian Magnesium Sulfat $20 \mathrm{Mg} / \mathrm{Kgbb}$ Intravena Sama Efektif Dengan Meperidin 0,5 $\mathrm{Mg} / \mathrm{Kgbb}$ Intravena Dalam Mencegah Menggigil Pasca Anastesi Umum. Denpasar. Universitas Udayana

Susilowati . (2017). Hubungan Indeks Massa Tubuh Dengan Kejadian Shivering Pada Pasien Spinal Anestesi Di Rs Pku Muhammadiyah Yogyakarta. Prodi D-Iv Keperawatan Jurusan Keperawatan Politeknik Kesehatan Kementrian Kesehatan Tahun 2017. 
Suswitha.(2018). Efektifitas Penggunaan Electricblan kepada Pasien Yang Mengalami Hipotermi Post Operasi Di Instalasi Bedah Sentral (IBS) Rumah Sakit Umum Daerah Palembang Bari Tahun 2018. Jurnal Ilmiah Kesehatan, Volume 8 No 1 Januari 2019.

Syam. (2013.) Efektivitas Penggunaan Prewarming Dan Water Warming Untuk Mengurangi Penurunan Suhu Intraoperatif Pada Operasi Ortopedi Ekstremitas Bawah Dengan Anestesi Spinal. Jurnal Anestesi Perioperatif [Jap. 2013;1(2): 86-93].

Valchanov, Et All. (2011). Anaesthetic An Perioperative Complication. England: Cambridge University Press) 